\author{
Revue \\ de l'histoire \\ Revue de l'histoire des religions \\ des religions \\ $2 \mid 2007$ \\ Divination et révélation dans les mondes grec et \\ romain
}

\title{
Reading Revelation : Allegorical Exegesis in Late Antique Alexandria
}

Lire la révélation : l'interprétation allégorique dans l'Alexandrie tardo-antique

\section{Blossom Stefaniw}

\section{(2) OpenEdition \\ Journals}

Electronic version

URL: http://journals.openedition.org/rhr/5259

DOI: 10.4000/rhr.5259

ISSN: 2105-2573

Publisher

Armand Colin

Printed version

Date of publication: 1 April 2007

Number of pages: 231-251

ISBN: 978-2200-92333-4

ISSN: 0035-1423

Electronic reference

Blossom Stefaniw, «Reading Revelation : Allegorical Exegesis in Late Antique Alexandria », Revue de I'histoire des religions [Online], 2 | 2007, Online since 01 June 2010, connection on 03 May 2019. URL http://journals.openedition.org/rhr/5259 ; DOI : 10.4000/rhr.5259 


\author{
BLOSSOM STEFANIW \\ University of Erfurt
}

\title{
Reading Revelation : Allegorical Exegesis in Late Antique Alexandria
}

This article presents a cultural approach to Alexandrian allegorical interpretation. It analyses it in terms of contemporary assumptions about the revelatory nature of traditional texts and how this belief resulted in casting the reader or commentator in the role of a contemplative and in the use of traditional texts in spiritual and moral education. Commentaries by Origen, Evagrius, Didymus, Hermeias, and Olympiodorus are examined. The controversial question of the Catechetical and Neoplatonic Schools of Alexandria is also addressed. The purpose of the article is to demonstrate how allegorical exegesis was coherent and meaningful within Late Antique Alexandrian culture and how allegorical exegesis was used in practice.

\section{Lire la révélation : l'interprétation allégorique dans l'Alexandrie tardo-antique}

Cet article propose une approche culturelle de l'interprétation allégorique alexandrine. L'analyse se fonde sur les positions de l'époque relatives à la nature révélée des textes traditionnels. Elle examine comment cette croyance a contribué à installer le lecteur dans le rôle d'un contemplatif et à donner aux textes traditionnels un rôle dans l'éducation spirituelle et morale. À cet effet, sont convoqués les commentaires d'Origène, d'Évagre, de Didyme, d'Hermeias et d'Olympiodore, ainsi que la question controversée des écoles catéchétique et néoplatonicienne d'Alexandrie. Le but de l'article est de démontrer à quel point l'exégèse allégorique était cohérente et signifiante au sein de la culture de l'Alexandrie tardive et comment l'exégèse allégorique était utilisée dans la pratique. 


\section{INTRODUCTION}

Allegorical interpretation in late antique Alexandria was driven by cultural beliefs, one of which was the view of traditional texts as vehicles of divine revelation which could be accessed by the committed reader using allegorisation. ${ }^{1}$ The purpose of this article is to set out how and why late antique Alexandrians saw allegorical exegesis as a tool for interpreting revelation and to identify how this tool was used in religious contexts. It also aims to demonstrate the usefulness of approaching allegorical exegesis as a thing driven primarily by cultural assumptions rather than individual technique or intercommunal power struggles. In my view, the most important aspect of this question for religious history is its implications for the role of the reader, because it explains how the reader could be cast in a contemplative role and why allegorical exegesis and the reading of allegorical commentaries became a characteristic part of late antique Alexandrian spiritual formation.

\section{Traditional Texts as Media of Revelation}

An explicit statement of this view of traditional texts as media of revelation can be found in Origen's Commentary on Matthew XIV, 12 where he describes the Gospel text as referring to "unspeakable and mysterious things" and as a "revelation of things fundamentally beyond mere letters". In the same passage Origen claims that he himself is "far from able to penetrate to the depths of what is here revealed". ${ }^{2}$ Late antique Alexandrian commentators manifest this assumption in statements regarding the divine or inspired authorship

1. I am using the term "revelation" in its broadest possible sense to signify any and all information about a higher spiritual realm rather than a message from a specific god regarding a specific situation. Also, my use of the term religion/religious refers not to cultic practice or confessional identity but to the cultural and philosophical aspect of dealing with questions of ultimate existential concern.

2. Der Kommentar zum Evangelium nach Mattäus. Üb. Hermann J. Vogt. Anton Hiersemann, Stuttgart (1993), Bd. 1-3, p. 48. 
of the text being interpreted, about the particular role of the interpreter, and in generating interpretations concentrated around the spiritual and moral. We will now examine passages of each type in turn.

The author of the text, whether Moses, Plato, Homer or the Holy Spirit, was believed to have had access to what late antique Alexandrians understood as ultimate reality in the course of composition and to have deposited this revelation in the text deliberately. The psalmist, other biblical authors, Plato and Homer are all treated by Alexandrian intellectuals as visionaries and sages "with revealed knowledge of the fate of souls and of the structure of reality" 3 . It is the belief in this inspired or divine authorship which is one of the motives for reading traditional texts as revelation.

Origen speaks of the methods by which the Holy Spirit inserts divine truth into the text in such a way as to alert the reader to the fact that there is a spiritual content beyond the plain narrative. The Holy Spirit crafts the text deliberately to contain but also to conceal the divine revelation, which Origen terms "the spiritual meaning" or "the secret meaning":

Moreover, we should also know that since the chief aim of the Holy Spirit was to keep the logical order of the spiritual meaning either in what is bound to happen or in what has already taken place, if anywhere He found that what happened according to the narrative could be fitted to the spiritual meaning, He composed something woven out of both kinds in a single verbal account, always hiding the secret meaning more deeply. (Peri Archon IV.2.6)

While Origen equivocates on the precise role of the Holy Spirit as having inspired or directly composed Scripture, he consistently sees the author of Scripture as working deliberately and with a view to revealing higher spiritual truths. ${ }^{4}$ This is evident for example in the Homily on Numbers 27.6:

3. Lamberton, Robert. Homer the Theologian: Neoplatonist Allegorical Reading and the Growth of the Epic Tradition. The Transformation of the Classical Heritage 9, edited by Peter Brown. Berkeley and Los Angeles: Univ. of California Press, 1986, p. 1. See also Dillon The Golden Chain, Aldershot 1990, p. 73.

4. Elizabeth Ann Dively Lauro, The Soul and Spirit of Scripture Within Origen's Exegesis. Leiden, Brill, 2005, p. 39, Origen Princ, Pref. 1.8, sc 252:84. 
We see what great care the Lord took in describing those stages so that their description would be introduced in a second place. For those names are recounted, granted with some differences, at the point when the children of Israel are said to have left each different place and to have camped at it... The stages are repeated twice in order to show two journeys for the soul. ${ }^{5}$

In his Commentary on Ecclesiastes 281, 2-24 Didymus responds to Porphyry's complaint about what he considers the inappropriate allegorising of the Bible. Since Porphyry recognises no higher wisdom or divine inspiration in the Scriptures, he considers them unqualified as objects of allegorical interpretation. Didymus, however, offers their divine inspiration as the very reason that they must be interpreted in a higher spiritual sense:

There is nothing which is inspired by the Holy Spirit which does not have a spiritual significance. Where there are teachings of the Holy Spirit, they must, if they are to take effect, be interpreted spiritually. ${ }^{6}$

Hermeias' Commentary on the Phaidros also includes a statement suggesting his belief in traditional texts as revelatory: "For often the myths about the gods use historical events and stories for the purpose of the teaching about the universals". ${ }^{7}$ For Hermeias, the historical and narrative content of traditional myths is only a means of revealing higher truths about the universals. ${ }^{8}$ In Olympiodorus we lack explicit statements on the divine or inspired authorship of Plato's writings but there is scholarly consensus that these were treated as inspired. ${ }^{9}$

The second effect of the cultural belief that traditional texts contained a revelation of spiritual truths is the definition of the interpreter's task which results from it. Origen, in his Commentary

5. Ibid., p. 186.

6. Bienert, Wolfgang. Allegoria und Anagoge bei Didymos dem Blinden von Alexandria. (Berlin, De Gruyter, 1972), p. 142. N.B. Where German editions have been used, the English translations used here are my own.

7. Bernard, Hildegard trans. Hermeias von Alexandrien. Kommentar zu Platons Phaidros, Philosophische Untersuchungen I (Tübingen, Mohr Siebeck, 1997), p. 33, Komm Phaed 28, $26 \mathrm{ff}$.

8. Ibid., p. 46-47.

9. L.G. Westernink, The Greek Commentaries on Plato's, Phaedo, Vol. 1, Olympiodorus (North Holland Pub. Co., Amsterdam, 1976), p. 15. 
on John, characterises the task of the interpreter as a matter of separating the sensible Gospel from the spiritual Gospel. Origen considers the interpreter's task to be "to transform the sensible Gospel into a spiritual one" in order to "penetrate to the deep things" and to "search out the truth that is in it". ${ }^{10}$ For Origen, the reader has access to divine revelation through the text, but he must strive to perceive it. Didymus similarly sees the task of the interpreter as apprehending the meaning of the text in relation to higher things or in a way that leads the mind upward (kat' anagogen). This is accomplished by moving beyond the initially apparent (associated in the commentaries with aistheta) and pursuing the higher ideas (associated in the commentaries with noeta) within it ${ }^{11}$. The interpreter must differentiate between lower and higher types of meaning and have the spiritual maturity to perceive the higher meaning. Allegorical interpretation is subsumed to the overall spiritual goal of leading the reader to spiritual perfection. ${ }^{12}$ Also for Evagrius, the purpose of the interpretation of Scripture is to expose the divine wisdom contained within it. The task of the interpreter is to cultivate and purify his perception to the point that he will consistently recognize divine wisdom. In the cases of Hermeias and Olympiodorus, we have very few surviving texts which do not include explicit statements about the task of the interpreter or its relation to the inspired nature of the text.

This belief also encouraged interpreters to see spiritual and moral truths in the texts, not only when treating passages which seem to invite such an interpretation but even, or perhaps especially, when confronted with particularly banal ones. When Origen reads Matthew's account of the miracle of the coin found in the fish's mouth, he sees in it an allegory for the reform of an avaricious soul:

You could apply this story to an avaricious person who has nothing else in his mouth but talk about money, when you see that he is healed by Peter who took the coin not only out of his mouth and out of his conversations but also out of his whole frame of mind which is the

10. Origen, Comm on John I. 10.

11. Bienert, p. 77.

12. Bienert, p. 93. 
symbol of all his appetite for money. You will surely say that such a person found himself in the sea and in the salty business of life and in the waves of thoughts and worries revolving around money and had the coin in his mouth, as long as he was unbelieving and avaricious, but he rose up out of the sea when he was caught by the hook of reason and experienced this great favor (through some Peter who taught him the truth) so that he no longer has the coin in his mouth, but instead words which bear the image of God. ${ }^{13}$

When Didymus the Blind reads Psalm 21:3 "You welcomed him with rich blessings and placed a crown of pure gold on his head", he immediately draws the conclusion that the precious stones must either represent "the virtues or those who have achieved the virtues". Further on in the same passage he surveys virtuous characters in biblical history so that the text becomes a pretext for discoursing to his students on the value of attaining various virtues. ${ }^{14}$ Again, when Psalm 21:4 speaks of "length of days for all eternity...". Didymus discovers a reference to the virtues in the midst of a digression on various reasons for wanting a long life and how the term "day" should be understood: ${ }^{15}$

A praiseworthy day is also each single practical virtue which is exercised. Just as the knowledge which is partial here is followed by a perfect and complete knowledge, so also in the practical virtues those people who are later proved righteous in the practical virtues will be virtuous in another manner.

Didymus is even able to find teachings on the life of virtue in the brief notes at the beginning of Psalm 35, "in view of the goal":

The ultimate goal worthy of our striving is perfect virtue, beyond which one need seek no other goal. We have laws for the sake of virtue; the giving of the laws is not the goal. We obey the warnings and rulings of the teacher of ethics; all this however is done for the sake of something else. Only the perfect, unsurpassable virtue, which is only achieved with

13. Vogt, trans. p. 256, Mattäuskommentar 256, XIII, 12.

14. Didymos der Blinde, Psalmenkommentar (Tura-Papyrus), Teil I. Kommentar zu Psalm, 20-21, ed. Trans. Louis Doutreleau, Adolphe Gesché und Michael Gronewald, Bonn, Rudolph Habelt Verlag, 1969, p. 44-45.

15. Ibid., p. 51. 
progress, is the goal. This is what any servant of God pursues. That is why it says "of David, the servant of the Lord". ${ }^{16}$

Also in his Commentary on Job, Didymus sees the text as referring to the virtues:

"Houses" in the plural must be understood as the plurality of virtues. Prudence is a house, courage is a house, gentleness and the other virtues, as it is written: "The fear of the Lord is a refuge for the righteous"; and so also justice. Overagainst these houses are the houses which the Lord tears down, for "the houses of the wicked the Lord tears down, but he protects the home of the widow". ${ }^{17}$

Didymus' belief that the text conveys revelation of spiritual things makes him confident that the text does not really refer to crowns, days, the end of a journey, or houses. Instead, he reads the text in such a way that it reveals divine truth about the nature and value of the life of virtue.

Several examples can also be taken from Evagrius' Commentary on the Psalms. In 11.3.1-3, Evagrius allegorises the attack made by "sinners" upon the "upright of heart" in terms of the spiritual struggle of the soul:

"For behold the sinners have bent their bow, they have prepared their arrows for the quiver, to shoot in the moonless night the upright of heart." Bow is the impure intellect. Arrow is the impassioned thought. Quiver is the worst habit, filled with impure thoughts. Moonless night is the soul's ignorance. ${ }^{18}$

The interpretation of Psalm 3:7 also concentrates on the moral and spiritual struggles of the monk:

"Arise, O Lord, deliver me, my God; for you have struck all who were in vain my enemies; you have broken the teeth of sinners." The teeth of

16. Didymos der Blinde, Psalmenkommenar (Tura-Papyrus), Teil IV Kommentar zu Psalm, 35-39, ed. Trans. Michael Gronewald, Bonn, Rudolf Habelt Verlag 1969, p. 1 zu Ps 35 1-2.

17. Didymos der Blinde, Kommentar zu Hiob (Tura Papyrus), Teil IV.1 Kommentar zu Hiob Kap, 12,1-16,8a ed. Trans. Ursula Hagedorn, Dieter Hagedorn und Ludwig Koenan, Bonn, Rudolf Habelt Verlag, 1985, p. 47 zu Hiob 12,5-6.

18. This provisional translation is available on http://www.ldysinger.com/ Evagrius/08_Psalms/00a_start.htm. 
sinners are irrational tempting thoughts occuring to us contrary to nature; making use of these many teeth the enemies draw near to us in order to eat our flesh (Ps 26.2) that is, those things that sprout forth from the flesh: "For the works of the flesh are manifest", (Gal 5:19) as the divine apostle says. ${ }^{19}$

Again, in his Scholia on Ecclesiastes, Evagrius reads the text as conveying divine truth about the life of virtue:

4.5 "The senseless man crosses his arms and devours his own flesh."

26. If the arms are the symbol of ascetic work, everyone who does not work righteousness folds his arms- and that, he says, is why such a person devours his own flesh, filling himself with the sins that spring from the flesh. ${ }^{20}$

Such interpretations indicate that the text is believed not to primarily be about the personal struggles of a historical figure or about conflicts experienced by King David. Scripture is interpreted to reveal universal moral truths.

Hermeias also finds a higher spiritual meaning in what we would consider incidental details, for example in the account of the setting of the dialogue of the Phaidros. ${ }^{21}$ His interpretations are driven by his belief that the entire dialogue has as its true skopos the task of revealing the nature of Beauty. Thus, when Socrates says that he is going for a walk outside the walls of the city, Hermeias takes this to indicate that Socrates is dedicated to a higher and better form of life, separate from the masses, and that Socrates is a role model for the way of life concerned with knowledge of spiritual beauty.

Another example can be taken from Olympiodorus, who treats the passage in the Phaedo which describes how Socrates rejects the instructions of the executioner not to talk after drinking the hemlock. Olympiodorus does not think that the text is written to record the historical event of the individual called Socrates receiving and disregarding certain instructions on a given day. Instead, this is what he considers the text to mean:

19. Ibid.

20. Casiday, trans. Scholia on Ecclesiastes in A. M. Casiday, Evagrius Ponticus, Routledge, New York 2006, p. 137.

21. Bernard, trans. p. 92, Komm. Phaed. I.1-20. 
Here Socrates represents the intellective and purificatory way of life, Crito the secondary life that depends on it, the man who prepares the poison the destructive cause which has the immediate control of matter and is also in charge of privation. This is why the man who makes the poison does not address Socrates directly, to intimate that there is not immediate contact between the lowest and the highest orders of existence.

Here the text has been expected to reveal deeper truths about the metaphysical structure of reality, and, in response to this expectation and the application of allegorical interpretation, has done so. Olympiodorus is thus able to find in it guidance for the philosophical student seeking to emulate the very "intellective and purificatory way of life" which Socrates is understood to represent. Olympiodorus is also quick to re-interpret Socratic irony as something less frivolous or flippant, finding a more serious moral meaning in Gorgias 489d7-8: "He may be speaking ironically, but at least he is making an honest point. For he is teaching him not to be rough but mild." 22

In summary, the ability of the text to perform its revelatory function is a result of the access to the divine enjoyed by its authors, whether themselves divine (as in Origen's Holy Spirit or Evagrius' Christ) or enjoying a view of what the commentators believed to be ultimate reality while composing the text as with the Psalmist, Homer or Plato. It is nothing more or less than the conviction of the readers and interpreters that traditional texts must have a spiritually significant content, regardless of appearances, which motivates allegorical interpretations toward the spiritual; the text itself is merely a vessel or medium in which revelation is contained.

\section{READERS AS CONTEMPLATIVES: Monastic and Philosophical Practice}

We can observe allegorical readers extracting the divine revelation from traditional texts in several contemplative/philosophical settings in and around Alexandria. While an initial view invites one to divide Alexandrian education neatly into three categories consisting of a

22. Tarrant, p. 110 (In Grg. 28.5, trans. Jackson et al. 1998, p. 201). 
Neoplatonist philosophical school, a Christian catechetical school, and separate monastic formation carried out in monasteries, closer examination of the available sources reveals a state of affairs much more complex and dynamic than this. The problematic nature of treating Alexandrian schools as religiously segregated has been established already. ${ }^{23}$ What concerns us here is to establish that the schools were not only religiously mixed but also followed analogous curricula in which allegorical interpretation played a key role.

The so-called catechetical school had an educational program closely related to the standard curriculum, including mathematics, geometry, and astronomy, as well as rhetorical, philosophical and ethical study of traditional texts for more advanced students. ${ }^{24}$ Referring to his education with the fourth-century teacher Hypatia, Synesius of Cyrene describes the standard view of geometry, arithmetic, astrology and philosophy as part of a progressive curriculum culminating in philosophy. ${ }^{25}$ Not only the curriculum constructed to cultivate the virtues and order and purify the mind step by step, but also the attachment to an exemplary teacher and making common cause with fellow-students served the overall educational goal of producing students capable of perceiving divine revelation. The last pagan teacher known to us, Olympiodorus, continues to pursue the standard curriculum of philosophical interpretation such that each text taught a particular virtue and the reader or listener could build up his own virtue in the right order by working through the curriculum appropriately. Thus the Gorgias teaches "constitutional" virtues while the Phaedo expounds purificatory virtues, and so on. ${ }^{26}$

23. See especially Watts, City and School; Christopher Haas, Alexandria in Late Antiquity: Topography and Social Conflict (Johns Hopkins University Press, Boston, 1997); Clemens Scholten, "Die alexandrinische Katechetenschule". Jahrbuch für Antike und Christentum, 38 (1995), 16-37, for a reappraisal of the traditional understanding of Origen's school as a "catechetical school".

24. Watts Edward, "The Student Self in Late Antiquity", in David Brakke et al. eds., Religion and the Self in Antiquity, (Bloomington, IN, 2005), 234251 , p. 251 , n. 56 . Cf. In origenem oratio panegyrica, 8-11 where Gregory reports being taught physics, astronomy, geometry as well as ethics by Origen.

25. Watts, City and School, p. 187. Cf. Synesius, Epistulae, 154.

26. Tarrant, p. 137. 
In the context of the educational agenda of purification and cultivation of the soul, Hermeias can describe the need for allegorical interpretation in terms of the ultimate salvation of the soul:

As a matter of custom one usually said after relating the myths, as a sort of postscript "And so the myth has been saved and it will save us, if we follow it, as he says at the end of the Politeia, or also 'and so the myth was lost', where this saying shows that we, if we follow the appearance of the myth (the literal interpretation), we will be lost just as appearances themselves are lost and have no definite being, but that we, if we follow the hidden vision (the allegorical interpretation) which the myth mysteriously indicates, will be saved, in that we rise up to the thought of the mythmaker himself and not just the myth". ${ }^{27}$

For both Origen and Didymus, penetrating to the allegorical meaning of the text was also a discipline which cultivated the mind and advanced the soul toward perfection. Those included in Didymus' circle of students and hearers had committed themselves to a course not just of mental but also of spiritual development, and the process of finding an allegorical interpretation was part of this project of psychagoge. Origen repeatedly describes allegorical interpretation as an insight into Scripture which is available to those who have advanced in their spiritual journey beyond the level of the simpler brethren and are striving to become perfect. ${ }^{28}$ Searching out and finding this higher interpretation of Scripture is an advanced spiritual discipline for the more mature. Origen often grapples with the interpretation of a passage and, unsatisfied with his results, attributes his struggle to inadequate spiritual advancement on his part.

Our evidence for how the late antique Alexandrian pedagogical agenda was pursued in Didymus' school and for the inclusion of elements of the standard philosophical curriculum in schools taught by Christians is found primarily in the Tura Papyri. These provide records of allegorical commentary on Biblical texts, including questions from students. ${ }^{29}$ Didymus' lectures contain lessons on rhetoric and logic which have nothing at all to do with imparting

27. Bernard, trans. p. 63. Komm. Phaed. $241 \mathrm{e} 8$ (Parenthetical statements are Bernard's).

28. Peri Archon IV.2.4.

29. The Tura Papyri are believed to be notes from twice-daily school lectures by Didymus taken down by a professional scribe. Layton, p. 3 . 
instruction in the Christian faith. For example, in the Commentary on Psalms, Didymus reviews what he refers to as a previous lesson on conceptual categorisation of attributes and terminology based on Euclid and Aristotle:

Thus we differentiate one thing from another conceptually. I have already spoken of colour and surface. Colour is one thing and surface is another. Of course they are inseparable. But we separate them conceptually. Colour allows of increase and decrease, surface area however does not. So colour and surface area are distinct, even though they cannot be separated and the one never exists without the other. This is what those say who construct proofs based on abstraction. We abstract one thing from the other conceptually, but not in fact, not in reality. So when we say that the line is a length without breadth, the perceptible line is not without breadth- we abstract the concept of line. ${ }^{30}$

Didymus also teaches informal logic:

And I would like to touch on a point of logic. The proofs are forms of scientific knowledge, for there are two types of conclusions. We do not wish to refer to the eristic or sophistic. The dialectical proof, which they also call epiceirematic, proceeds on the basis of generally agreed upon concepts. This type of proof is derived from that which people generally concede, and not from the nature of things. The apodeictic proof is based on the nature of things themselves, not on the opinions of people about them, but from the nature of things about which we are trying to achieve scientific knowledge. So it is impossible to achieve a watertight proof on the basis of negative definitions. Proofs are based on positive definitions. So if I want to prove that humans are rational, I do not say "man is not unsouled", because most other creatures are also not unsouled, including those which are not rational. So I have to set up the proof like this: "Man is capable of knowledge, anything that is capable of knowledge is rational, therefore man is rational". ${ }^{31}$

30. Didymos der Blinde, Psalmenkommentar (Tura-Papyrus), Teil I. Kommentar zu Psalm 20-21. Ed. Trans. Louis Doutreleau, Adolphe Gesché und Michael Gronewald. Bonn, Rudolph Habelt Verlag, 1969, p. 103 zu Psalm 21,2 (Didymus here refers to Gellius N. A: 1,20,9, Arist. Top. 143B11, Sextus Emp. Adv. Geom. 3,37).

31. Ibid., p. $207 \mathrm{zu}$ Psalm 21,27 (refering to Arist. S. E. 171 b 6ff, Top. 100 b 23ff., Arist. S. E. 169 b 20ff, 171 b 6ff, Arist. S. E. 171 b 6ff, Top. 100 a 30ff, 100 b 6ff, Arist. Top. 100 a 27ff. See also Psalmenkommentar III p. 247 zu 38,12 for discussion of how to prove contraries. 
Didymus is here making a quick review of the knowledge in logic and rhetoric which he expects his students to have acquired before they attempt the allegorical interpretation of the Scriptures. The fact that he makes repeated detours from the verses with which the class is concerned to reinforce this knowledge suggests that he considers it a necessary prerequisite to the higher mental activity of extracting the divine revelation contained in Scripture.

The sources on monastic formation indicate that the curriculum through which the monk was required to progress, and the goal he was ultimately pursuing, were both closely related to the educational agenda of the urban schools. Edward Watts has suggested one reason for this in the keenness of Athanasius to associate asceticism with "true philosophy", discouraging Christian teachers from remaining in the cities and propounding doctrines disruptive to Athanasius' own purposes. ${ }^{32}$ On that understanding of the historical situation, we could see monastic formation developing as an alternative to school philosophy, but doing so self-consciously enough that the very pedagogical structures it sought to supersede can be clearly traced in its own curriculum and agenda and in the means employed to achieve its goal.

A letter of Evagrius to a fellow monk witnesses to the understanding of the goal of the monastic life as the same as that of the philosophical life:

Now I have set myself the goal of not leaving my cell. Our struggle is for the contemplation of that which is and of the Holy Trinity, and the demons wage a great war against us to hinder us from knowing. ${ }^{33}$

As we will see below, the goal of "the contemplation of that which is", well known as the summit of Neoplatonist philosophy, could be achieved by employing the nous, or higher intellect. The intellect was only free to function properly when the body and passions had been brought into order. For Evagrius, the contemplative recitation of the Psalms could calm the passions, thus allowing

32. Watts, City and School, p. 170.

33. Gabriel Bunge, trans. Evagrios Pontikos: Briefe aus der Wüste. Paulinus Verlag, Trier, 1986, p. 276. Ep. 58.2. 
the mind to move upwards into prayer and the "proper activity" of the nous. This understanding is reflected in his treatise on prayer:

83. "Psalmody calms the passions and puts to rest the body's disharmony; prayer arouses the nous to activate its own proper activity".

84 "Prayer is the power befitting the dignity of the nous; it is the nous" highest and purest power and function. ${ }^{34}$

Evagrius speaks of the practice of reading the Scriptures as a means of achieving purity and disentangling the nous from worldly concerns:

You also know through our Lord that the reading of the divine Scriptures is of great use to purity, since it turns the intellect away from the cares of this visible world, out of which the corruption of the impure thought arises, which binds the intellect to physical things through the passions. So speak constantly with the brothers, so that they read the Scriptures at the accustomed hour and "love not the world and what is in it"... 35

The reading of Scriptures is set up as the opposite of concern with worldly things, as a step in freeing the mind from sensual thoughts and reorienting it to the spiritual life. In the same letter, Evagrius goes on to describe the reading of the Scriptures as a sort of therapy for the mind:

Nothing else effects pure prayer like the reading of the divine Scriptures. The life of virtue cuts off the passions, when there is desire and grief and anger. Reading however uproots the remaining minor worldly thoughts out of us and initiates our intellect in the formless contemplation of the nature of divine knowledge which our Lord calls a 'chamber' allegorically in his Gospel, in which we will see the holy and hidden Father. ${ }^{36}$

For Evagrius and the desert monks, allegorical interpretation was part of the daily ascetic discipline of the contemplation of Scripture: the monk was to repeat a verse or passage of Scripture and meditate upon it until he was able to perceive the divine wisdom within it. ${ }^{37}$ In the desert, allegorical interpretation became more a part of spiritual

34. Luke Dysinger. Psalmody and Prayer in the Writings of Evagrius Ponticus. OUP, 2005. p. 70. Dysinger's translation.

35. Bunge, p. 215, Ep 4.3.

36. Ibid., Ep 4.5.

37. Dysinger, p. 15. 
formation than ever, being given a specific role in Evagrius' threestep "curriculum" of spiritual progress, itself borrowed from Stoicism, under the name of theoria physike. This type of contemplation required the monk to attempt to perceive the spiritual realities contained in Scripture with a concentrated mind, that is, one distracted neither by physical needs or emotional disorder. The monastic practice of chanting Psalms was a discipline used to develop the special perception of Scripture's spiritual significance, as described in Evagrius' Commentary on the Psalms 137,1.1:

"And before the angels I will chant Psalms to you". To chant Psalms before the angels is to sing Psalms without distraction: either our mind is imprinted solely by realities symbolized by the Psalm, or else it is not imprinted. Or perhaps the one who chants Psalms before the angels is he who apprehends the meaning of the Psalms. ${ }^{38}$

That the reading and chanting of the Psalms was a contemplative practice intended to allow the mind to achieve perception of the divine revelation contained beyond the images of the text is confirmed by the intricate association of psalmody and prayer in monastic liturgical practice, such that they are sometimes refered to synonymously. ${ }^{39}$

The goal of the monastic life, like that of the philosophical life, was the contemplation of what the commentators considered ultimate reality. Since this ultimate reality was revealed through traditional texts, allegorical and contemplative reading of these texts could allow the mind access to the highest truths, so that allegorical interpretation served the overall pedagogical goals of late antique Alexandrian higher education, positioned at the summit of a curriculum intended to order the passions and cultivate the mind to the point that it was prepared to comprehend divine truth.

On the subject of allegorisation in Neoplatonism, Dillon, on the basis of having searched the Neo- and Middle Platonist corpus for references to or instructions on allegorical exegesis of Plato in vain, concludes that the "rules" by which it was performed were not taught or recorded systematically, but were instead a matter of practice

38. Dysinger, p. 101

39. Ibid., p. 48-9. 
internalised by "sitting at the feet of one's master". ${ }^{40}$ This state of affairs supports my hypothesis that allegorical interpretation was governed by cultural assumptions rather than a set technique, as one would expect a technique to be reducible to rules and teachable. Instead, by initiation into the educational culture presented to them through the higher school curriculum, and by sharing the same cultural assumptions about the nature of the text and the purpose of reading it, late antique Alexandrians acquired an awareness of what constituted an appropriate allegorical interpretation. By internalising the interpretive practice of the schools, they themselves could also generate acceptable allegorical interpretations and perceive themselves thereby to be extracting the divine revelation from the text. Thus the curriculum was not primarily focused on imparting to the student a catalogue of facts, rules or methods, but rather on developing his mind in a particular direction.

\section{Readers as Contemplatives: Theoretical Considerations}

Two questions arise in connection with the view of traditional texts as media of revelation, namely, by what means the intelligible content of the text could be accessed and under what circumstances an interpretation could be trusted as legitimate.

In answering the first question, we must turn to the philosophy of Plotin. It is highly improbable that Origen, Didymus, Evagrius, Hermeias and Olympiodorus carefully studied the Enneads and then deliberately worked out a theory of a need for allegorical interpretation. What we can observe, however, are ideas lurking behind the work of these Alexandrian interpreters in the form of implicit assumptions which are also present in Plotin in the form of explicit scholarly argumentation.

Plotin holds discursive reasoning and the use of ordinary language in dialectical argument to be perfectly appropriate and functional

40. John Dillon, "Image, Symbol and Analogy: Three Basic Concepts of Neoplatonic Allegorical Exegesis", in John Dillon, The Golden Chain, Aldershot, 1990, p. 248. 
for purposes of gaining knowledge about the world. Other means are needed, however, to gain knowledge of the nous or One. ${ }^{41}$ One must engage in what has often been translated as intuitive thought, but can more accurately be described as employing the nous rather than engaging in dianoia. The nous is credited with a capacity for perfect, spontaneous insight into intelligible realities. ${ }^{42}$ Thus the reader can access the revelation hidden in his text by using noetic, intuitive, non-discursive thought when confronted with the narrative of the text. This shift in perspective then allows him to perceive not just the plain literal words but the higher revelation behind them. The reader must think in the same manner as the writer who composed the text from the perspective of visionary knowledge of intelligible reality.

Another relevant point in Plotinian thought is the conviction that the unity of the knower and the object of knowledge is a condition absolutely necessary for true knowledge, such as knowledge of intelligibles. ${ }^{43}$ Unity of knower and known obviously precludes discursive thought. So if allegorical interpretation, having as its object intelligible realities, requires non-discursive thought in order to perceive those realities, and if knowledge of intelligible realities is more perfect the more the knower is unified with the known, we may describe the task of the reader in performing allegorical interpretation as dependent on his finding himself in a state of unity, or at least harmony, with the intelligible object of knowledge. That is, an interpreter can interpret better the more his mind is attuned to the higher spiritual realities he is trying to uncover from the text before him. This brings us to the second question.

Answering the second question is a matter of discovering how members of late antique Alexandrian religious culture considered it possible to achieve adequate attunement of the mind with spiritual realities. The idea of the necessity of the interpreter's mind being

41. Alfino Mark Richard, "Plotinus and the Possibility of Non-Propositional Thought", Ancient Philosophy, 8, 2, 1998, p. 281.

42. Ibid., p. 276 on Plotinus, Enneads V1.11 and V5.1.

43. Rappe Sara, Reading Neoplatonism: Non-discursive Thinking in the Texts of Plotinus, Proclus and Damascius, CUP, 2000, p. 33. 
governed by the same spirit that inspired the author is stated by Origen in the midst of his struggle to understand a certain text of Matthew. While he finds he must capitulate, he is confident that someone else can find the higher interpretation as long as they use "the spirit of Christ who said these things" rather than relying on "human means":

It is probable that other details could be considered by someone else who examines the matter more carefully, the exegesis and interpretation of which appears to me to be beyond human means and to require the spirit of Christ who said these things, so that they are understood as Christ said them (Comm in Matt XIV, 6). ${ }^{44}$

The basic requirement of the conformity of the interpreter's mind with that of the author of the text is set out also in Didymus the Blind's prologue to his Commentary On Zachary, where he states that since Scripture contains spiritual wisdom, it must be interpreted spiritually, but such an interpretation can only be given by exegetes who have the divine spirit to lead them, and can only be understood by those who are spiritually prepared. For these reasons Didymus considers prayer the proper preparation to study of the Scriptures. ${ }^{45}$ Similarly, in his interpretation of Proverbs Didymus describes the individual capable of understanding Scripture as one possessing divine wisdom (ho kata theon sophos). ${ }^{46}$ The individual capable of perceiving the higher, noetic, revelatory content of Scripture will have special divine wisdom:

One must interpret Scripture according to its deeper meaning. This is done by the man who is truly wise in the things of God. When (Scripture) is not interpreted thus, but insufficiently, neither its greatness nor that of its author is manifest. ${ }^{47}$

In his Commentary on the Psalms, Didymus expresses the need for special insight metaphorically:

One must also say the following: It is impossible to understand grammatical words if one has no insight into the (meaning of) the letters, and it is not possible to understand philosophical words if one

44. Vogt, trans. p. 40, Mattäuskommentar, XIV, 6.

45. This is a paraphrase of Bienert's German in Bienert, 73.

46. Bienert, p. 76.

47. Psalmenkommentar III, p. 65 zu Psalm 35,13. 
has no knowledge of the theory which initiates one into them. In the same way it is also impossible to understand the things of God without godly insight. ${ }^{48}$

Godly insight is required if one is to read the things of God, just as one must know one's letters in order to read words.

Evagrius describes the act of perceiving the divine wisdom, both in Scripture and in creation, as a type of contemplation called theoria physike. This type of contemplation consists in applying the rehabilitated nous to Scripture (or creation). The properly functioning nous of the human individual is able to recognize divine wisdom because divine wisdom is also nous. (This is consistent with Origen's thought as reflected in De Principiis 4.2.4 where, when he speaks of gathering the meaning of Scripture, the term translated "meaning" is actually nous. ${ }^{49}$ ) Clearly then, the key to legitimate interpretation on this scheme is the successful rehabilitation and proper functioning of the nous. For Evagrius, this is achieved by purifying the body through askesis and disciplining the passions of the psyche so that it no longer interferes with the function of the nous. Thus it is the askesis and the spiritual maturity of the interpreter which guarantees the legitimacy of the interpretation.

The same differentiation of the appropriate uses of dialectical vs. intuitive thought we identified in Plotin also appears in Evagrius:

The kingdom of heaven has no need of a soul confident in dialectic, but rather a contemplative soul. Dialectic can also be found in impure souls, contemplation however is found only in pure souls. ${ }^{50}$

Evagrius couples the ability to use contemplative thought with the purity of the soul, which is consistent with his ascetic program. In the Epistula Fidei, Evagrius explains that the capacity of the nous for contemplation is natural and instinctive as soon as the nous is rehabilitated, rather than requiring instruction as do lower parts of the mind such as the rational mind which would be used for dialectical reasoning:

48. Psalmenkommentar III, p. 145-7 zu Psalm 31.

49. Dively Lauro, p. 51.

50. Bunge, p. 282-3. Ep. 62.1. 
For just as sense perception is competent in sensory things, so the intellect (nous) in intelligible things. At the same time one must say that God, when he created in the beginning, made physical criteria unlearnable. No one has ever taught the face to perceive colour and form nor hearing to recognise noises or voices, nor smell pleasant or unpleasant scents, nor taste juices and liquids nor touch soft or hard, warm or cold. In the same way no one needs to teach the intellect to turn itself toward intelligible things. Just as the organs of sense, when they are sick, just require healing and then easily take up their proper function, so also the intellect which is bound to the flesh and filled with the images which arise out of it requires faith and an upright life, which places it "as hinds feet on high places". ${ }^{51}$

The need to use the nous in order to perceive the revelation deposited in Scripture, along with the belief that the nous requires rehabilitation through disengagement from the body and the passions in order to function properly, explains why allegorical interpretation appears in a monastic and contemplative context where these requirements could be met through asceticism.

The remaining texts of Hermeias and Olympiodorus do not include explicit evidence for how they believed the interpreter could extract revelation from the text or the basis for a legitimate interpretation. However, the persistent arrangement of the educational curriculum, which both Hermeias and Olympiodorus taught, in advancing steps of virtue implies that the individual who has advanced through the entire course of Platonic exegesis has thereby cultivated a high level of virtue, so that the teacher of exegesis will have achieved his expertise in interpretation on the basis of advanced moral and spiritual development.

Thus these commentators believe a legitimate interpreter must be some one who has cultivated himself morally and spiritually, progressing through a curriculum of mental development and/or ascetic discipline. An adequate interpretation arises out of the interpreter's ability to apply his purified nous to the text and perceive the revelation contained in it by using the same noetic type of thought experienced by the author of the text when in direct contact with intelligible reality.

51. Bunge, p. 302. Ep. 63.38 . 


\section{Conclusions}

Using an alternative approach to late antique Alexandrian allegorical interpretation and identifying key cultural ideas governing this distinct way of reading has allowed us to achieve a coherent explanation not only for the interpretations reached but also for the social contexts in which interpretations were performed and for their religious significance. In the view of allegorical interpretation as a tool for accessing divine revelation in traditional texts we have identified a religious practice which has its basis in common philosophical and intellectual culture rather than particular religious doctrines or cultic practices. The view of the text as a medium of divine revelation generates distinct roles for the writer and reader of the text, necessitating a way of reading appropriate to the intelligible significance of the text. Allegorical readers soon find themselves in the role of contemplatives because of the particular beliefs about human capacity for knowledge, reservations about the adequacy of ordinary language for communicating certain knowledge, and assumptions regarding the purpose of education current in the intellectual culture of their day.

blossomstefaniw@aol.com 